\title{
PENGEMBANGAN MEDIA PEMBELAJARAN FISIKA BERBASIS ANDROID DI SMA NEGERI 3 NGABANG
}

\author{
Nyemas Wulandari ${ }^{1 *}$ \\ ${ }^{1}$ Teknologi Pendidikan, Fakultas Keguruan dan Ilmu Pendidikan Universitas Tanjungpura, \\ Pontianak, Indonesia \\ *email: nyemaswulandariwd@gmail.com
}

\section{Received: 14 Oktober 2019 Accepted: 20 Juni 2020 Published: 30 Juni 2020}

\begin{abstract}
Abstrak
Penelitian ini bertujuan untuk menghasilkan media pembelajaran fisika berbasis android. Penelitian ini merupakan penelitian dan pengembangan (R\&D) yang mengacu pada model ADDIE yang terdiri dari lima tahap, yaitu analisis (analyze), desain (design), pengembangan (development), implementasi (implementation), dan evaluasi (evaluation). Dari hasil validasi ahli media didapatkan persentase sebesar $87,42 \%$ dengan kriteria sangat baik, hasil validasi ahli materi didapatkan persentase sebesar $76,67 \%$ dengan kriteria sangat baik, dan hasil validasi ahli desain didapatkan persentase sebesar $80 \%$ dengan kriteria sangat baik. Hasil respon siswa uji coba didapat rata-rata uji coba kelompok one to one sebesar 85,83 \% dengan kriteria positif, uji coba kelompok sedang rata-rata sebesar 89,38\% dengan kriteria positif, dan uji coba kelompok besar dengan rata-rata sebesar 95,21\% dengan kriteria positif. Dari hasil validasi dan uji coba produk menunjukkan bahwa media pembelajaran fisika berbasis android layak untuk digunakan dalam pembelajaran fisika.
\end{abstract}

Kata kunci: media pembelajaran, fisika, android

\begin{abstract}
This research aims to produce physics learning media based on android. This research is Research and Development $(R \& D)$ refer to ADDIE model, has five Steps they are: Analyze, Design, Development, Implementation, and Evaluation. Results of the validation media experts obtained a percentage value of $87,42 \%$ with excellent criteria, the results of material expert validation of $76,67 \%$ with excellent criteria, the results of material expert validation of $80 \%$ with excellent criteria. The results of the response of students testing an android-based learning media obtained an average of one to one group trial of 85,83\% with positive criteria, a moderate group trial of 89,38\% with a positive criteria, and a large group trial with an average of 95,21\% with positive criteria. From the results of product validation and trials show that android-based learning media are suitable for use in physics learning.
\end{abstract}

Keywords: learning media, physics, android

How to cite (in APA style): Wulandari, N. (2020). Pengembangan media pembelajaran fisika berbasis android di SMA Negeri 3 Ngabang. Jurnal Pendidika Informatika dan Sains, 9(1), 21-27

Copyright $\odot 2020$ Nyemas Wulandari DOI: $10.31571 /$ saintek.v9i1.1296

\section{PENDAHULUAN}

Perkembangan ilmu pengetahuan dan teknologi yang begitu pesat, profesionalisme guru tidak cukup hanya dengan kemampuan membelajarkan peserta didik, tetapi juga dituntut untuk mampu beradaptasi dengan perkembangan teknologi agar dapat mengembangkan media pembelajaran yang 
interaktif dan kreatif. Peranan teknologi informasi dan komunikasi dalam pembelajaran selain membantu siswa dalam belajar, juga memiliki peranan yang cukup berpengaruh untuk guru terutama dalam pemanfaatan fasilitas untuk kepentingan memperkaya kemampuan mengajar (Rusman, 2011). Dalam usaha menciptakan pembelajaran yang interaktif dan kreatif maka diperlukan penggunaan media pembelajaran yang interaktif dan menarik.

Media adalah alat perantara dalam berbagai jenis kegiatan komunikasi (Hermawan, 2015). Menurut Asyhar (2011), media yaitu suatu sarana atau perangkat yang berfungsi sebagai perantara atau saluran dalam suatu proses komunikasi antara komunikator dan komunikan. Salah satu alat komunikasi yang sudah dimiliki oleh peserta didik yang bisa dimanfaatkan sebagai media pembelajaran yaitu handphone dengan sistem operasi android. Menurut Safaat (2013) android adalah sebuah sistem operasi untuk perangkat mobile berbasis linux yang mencakup sistem operasi, middleware dan aplikasi, android menyediakan platform terbuka bagi para pengembang untuk menciptakan aplikasi mereka sendiri untuk digunakan oleh bermacam peranti bergerak. Android umumnya digunakan di smartphone dan juga tablet PC.

Mata pelajaran fisika adalah salah satu mata pelajaran yang diajarkan di SMA Negeri 3 Ngabang. Berdasarkan hasil pengamatan yang dilakukan di SMA Negeri 3 Ngabang pada saat kegiatan belajar mengajar guru menyampaikan materi pelajaran fisika secara klasikal dengan metode ceramah, pemberian tugas dan kegiatan tanya jawab. Minimnya media pembelajaran interaktif membuat pembelajaran fisika hanya berpusat pada guru, hal ini cenderung membuat siswa bosan yang pada akhirnya siswa menjadi pasif. Selain itu, sebagian besar siswa telah memiliki smartphone dengan sistem operasi android. Oleh karena itu pengembangan media pembelajaran berbasis android tepat dilakukan untuk membantu siswa belajar fisika secara lebih efektif. Media pembelajaran berbasis android terutama pada bidang sains telah banyak dikembangkan dan hasilnya mampu membuat pembelajaran menjadi lebih efektif (Astuti, Sumarni and Saraswati, 2017; Muyaroah and Fajartia, 2017; Yektyastuti and Ikhsan, 2016). Berdasarkan hal tersebut, tujuan penelitian ini adalah mengembangkan media pembelajaran berbasis android untuk siswa di SMA Negeri 3 Ngabang dengan subjek pengembangan mata pelajaran fisika. Selain mempersiapkan siswa dalam mengikuti perkembangan teknologi, pengembangan ini juga diharapkan dapat dijadikan alat bantu guru maupun siswa dalam belajar fisika, sehingga belajar fisika menjadi menyenangkan. Adapun cakupan materi yang berkaitan dengan pengembangan adalah gerak lurus beraturan dan gerak lurus berubah beraturan.

\section{METODE}

Penelitian ini diadakan di SMA Negeri 3 Ngabang pada jurusan IPA. Sesuai dengan tujuan umum dalam penelitian ini yaitu pengembangan media pembelajaran fisika berbasis android maka penelitian ini termasuk pada penelitian dan pengembangan. Desain penelitian yang digunakan adalah Research and Development (R\&D) dengan model ADDIE yang terdiri dari lima tahap, yaitu: analisis (analyze), desain (design), pengembangan (development), implementasi (implementation), dan evaluasi (evaluation) (Pribadi, 2016).

Tahap analisis (analyze) merupakan proses analisis kebutuhan, mengidentifikasi masalah dan melakukan analisis tugas. Pada tahap analisis kegiatan yang dilakukan dengan mengumpulkan datadata berupa hasil wawancara terhadap guru dan siswa untuk mengetahui dan menguraikan permasalahan yang dihadapi sekolah berkaitan dengan penggunaan media yang dibutuhkan dalam penelitian. Tahap desain (design) merupakan proses membuat rancangan (story board). Pada tahap ini kegiatan yang dilakukan adalah membuat rancangan awal media pembelajaran interaktif berbasis android dengan powerpoint, Ispring Suite8 dan Website 2 APK Builder. Tahap pengembangan (development) merupakan proses mewujudkan desain menjadi produk yang siap divalidasi dan diuji cobakan. Tahap pengembangan adalah tahap dimana peneliti melakukan validasi oleh 1 orang validasi ahli media, 1 orang validasi ahli desain dan 1 orang validasi ahli materi. Tahap implementasi (implementation) merupakan proses menerapkan media yang dikembangkan. Pada proses ini 
dilakukan uji coba kelompok yang dilakukan melalui tiga tahap yaitu uji one to one terhadap 1 siswa berkemampuan rendah, 1 siswa berkemampuan sedang, dan 1 siswa berkemampuan tinggi; uji coba kelompok sedang terhadap 4 siswa berkemampuan rendah, 4 siswa berkemampuan sedang, dan 4 siswa berkemampuan tinggi; dan uji coba kelompok besar terhadap 36 siswa. Tahap evaluasi (evaluation) merupakan proses penilaian akhir dari pengembangan. Kegiatan yang dilakukan pada tahap ini adalah finalisasi dari revisi dan hasil uji kelompok besar. Pada tahap ini peneliti hanya melihat respon siswa terkait penggunaan media pembelajaran fisika berbasis Android di SMA Negeri 3 Ngabang.

Teknik pengumpulan data yang digunakan dalam penelitian ini adalah teknik pengukuran dan teknik komunikasi tidak langsung dengan alat pengumpul data tes hasil belajar berbentuk tes pilihan ganda angket respon siswa yang berisi pernyataan positif dan angket validasi yang terdiri dari angket validasi ahli materi dengan aspek isi materi, contoh soal dan soal beserta kunci jawaban; validasi ahli desain dengan aspek tujuan pembelajaran kaitan dengan SK/KD/ Kurikulum/Materi, kontekstualitas dan aktualitas pembelajaran, soal dan fisik aplikasi; dan validasi ahli media dengan aspek dengan aspek kebahasaan, penyajian, efek media terhadap pembelajaran, tampilan menyeluruh yang dibuat berdasarkan skala Likert. Data hasil validasi ahli materi, ahli desaina dan ahli media dihitung dan dikategorikan pernyataan positif ke dalam rentang nilai 4 dengan kategori yaitu: (4) sangat baik, (3) baik, (2) cukup baik, dan (1) kurang baik, Rentang nilai penilaian hasil validasi oleh ahli materi dan media kemudian dipersentasekan, persentase hasil validasi ahli materi dan media dikategorikan berdasarkan Tabel 1 (Riduwan, 2010).

\section{Tabel 1. Rentang Kategori Nilai Hasil Validasi Ahli}

\begin{tabular}{ccc}
\hline No & Interval Nilai \% & Kategori \\
\hline 1. & $76-100$ & Sangat Baik \\
2. & $51-75$ & Baik \\
3. & $26-50$ & Cukup Baik \\
4. & $0-25$ & Kurang Baik \\
\hline
\end{tabular}

Langkah selanjutnya adalah menilai kelayakan media pembelajaran untuk diimplementasikan pada mata pelajaran fisika di SMA Negeri 3 Ngabang, yaitu dengan mengklasifikasikan jawaban butir instrument menjadi lima pilihan. Setiap indikator yang diukur diberikan skor rentang 1-5, yaitu 5 (sangat layak), 4 (layak), 3 (kurang layak), 2 (tidak layak), dan 1 (sangat tidak layak). Kategori kelayakan berdasarkan kriteria seperi pada Tabel 2 (Arikunto, 2009).

Tabel 2. Kriteria Kelayakan Media

\begin{tabular}{ccc}
\hline No & $\begin{array}{c}\text { Skor dalam persen } \\
\text { \% }\end{array}$ & Kategori \\
\hline 1. & $<21$ & Sangat Tidak Layak \\
2. & $21-40$ & Tidak Layak \\
3. & $41-60$ & Kurang Layak \\
4. & $61-80$ & Layak \\
5. & $81-100$ & Sangat Layak \\
\hline
\end{tabular}

\section{HASIL DAN PEMBAHASAN}

\section{Hasil validasi ahli media, materi dan desain}

Adapun hasil validasi oleh ahli media dapat dilihat pada Tabel 3. Berdasarkan hasil validasi oleh ahli media menunjukkan bahwa media pembelajaran interaktif berbasis android memiliki hasil 
persentase sebesar 87,42 , sehingga media pembelajaran interaktif berbasis android termasuk pada kategori sangat baik dan layak untuk diujicobakan kepada siswa.

Tabel 3. Hasil Validasi Ahli Media

\begin{tabular}{lc}
\hline \multicolumn{1}{c}{ Aspek } & Persentase Skor \\
\hline Kebahasaan & 88.00 \\
Penyajian & 80.00 \\
Efek Media terhadapPembelajaran & 95.00 \\
TampilanMenyeluruh & 86.67 \\
Persentase rata-rata & 87,42 \\
\hline
\end{tabular}

Adapun hasil validasi oleh ahli materi dapat dilihat pada Tabel 4. Hasil validasi oleh ahli materi seperti disajikan pada Tabel 4 menunjukkan bahwa media pembelajaran interaktif berbasis android memiliki hasil persentase sebesar 76,67, sehingga media pembelajaran interaktif berbasis android masuk pada kategori sangat baik dan layak untuk diujicobakan kepada siswa.

Tabel 4. Hasil Validasi Ahli Materi

\begin{tabular}{|c|c|}
\hline Indikator & Persentase Skor \\
\hline $\begin{array}{l}\text { Kesesuaian isi materi dengan kompetensi dasar (KD) dan tujuan } \\
\text { pembelajaran }\end{array}$ & 80 \\
\hline Pengembangan indikator & 80 \\
\hline Kebenaran konsep materi ditinjau dari aspek keilmuan & 80 \\
\hline Kejelasan topik pembelajaran & 80 \\
\hline Keruntunan materi & 80 \\
\hline Cakupan materi & 60 \\
\hline Ketuntasan materi & 80 \\
\hline $\begin{array}{l}\text { Kesesuaian tingkat kesulitan dengan perkembangan kognitif } \\
\text { pesertadidik }\end{array}$ & 80 \\
\hline Kejelasan contoh & 80 \\
\hline $\begin{array}{l}\text { Ketepatan materi dan contoh untuk mengembangkan kemandirian } \\
\text { belajar }\end{array}$ & 60 \\
\hline Kebenaran kunci jawaban yang disajikan & 80 \\
\hline Muatan aspek kognitif, pada materi yang disampaikan & 80 \\
\hline Persentase rata-rata & 76.67 \\
\hline
\end{tabular}

Adapun hasil validasi oleh ahli desain dapat dilihat pada Tabel 5.

Tabel 5. Hasil Validasi Ahli Desain

\begin{tabular}{lc}
\hline \multicolumn{1}{c}{ Indikator } & $\begin{array}{c}\text { Persentase } \\
\text { Skor }\end{array}$ \\
\hline Judul media & 80 \\
Penilaian Aspek Tujuan Pembelajaran, Kaitan dengan SK/KD/ & \\
Kurikulum/ Materi & 80 \\
Penilaian Aspek Konstekstualitas dan Aktualitas Pembelajaran & 80 \\
PenilaianAspekSoal & 80 \\
PenilaianAspekfisikAplikasi & 80 \\
Persentase rata-rata & 80 \\
\hline
\end{tabular}


Hasil validasi ahli desain seperti disajikan pada Tabel 5 menunjukkan bahwa media pembelajaran interaktif berbasis android memiliki hasil persentase sebesar 80, sehingga media pembelajaran interaktif berbasis android masuk pada kategori sangat baik dan layak untuk diujicobakan kepada siswa.

\section{Hasil respon pada uji one to one}

Adapun respon siswa pada uji one to one dapat dilihat pada Tabel 6.

Tabel 6. Hasil Respon Siswa pada Uji One to One

\begin{tabular}{ccccccccccc}
\hline & \multicolumn{10}{c}{ Pernyataan } \\
\cline { 2 - 11 } & $\mathbf{1}$ & $\mathbf{2}$ & $\mathbf{3}$ & $\mathbf{4}$ & $\mathbf{5}$ & $\mathbf{6}$ & $\mathbf{7}$ & $\mathbf{8}$ & $\mathbf{9}$ & $\mathbf{1 0}$ \\
\hline rata-rata & 3.33 & 3.67 & 3.33 & 3.33 & 3.67 & 3.67 & 3.67 & 3.00 & 3.00 & 3.67 \\
$\begin{array}{c}\text { Persentase } \\
\text { \%total }\end{array}$ & 83.33 & 91.67 & 83.33 & 83.33 & 91.67 & 91.67 & 91.67 & 75.00 & 75.00 & 91.67 \\
\hline
\end{tabular}

Tabel 6 menunjukkan hasil persentase total respon siswa 85,83 dengan kriteria positif.

Hasil Respon pada Uji Kelompok Sedang

Adapun respon siswa pada uji kelompok sedang dapat dilihat pada Tabel 7.

Tabel 7. Hasil Respon Siswa pada Uji Kelompok Sedang

\begin{tabular}{ccccccccccc}
\hline \multirow{2}{*}{ Siswa } & \multicolumn{10}{c}{ Pernyataan } \\
\cline { 2 - 11 } & $\mathbf{1}$ & $\mathbf{2}$ & $\mathbf{3}$ & $\mathbf{4}$ & $\mathbf{5}$ & $\mathbf{6}$ & $\mathbf{7}$ & $\mathbf{8}$ & $\mathbf{9}$ & $\mathbf{1 0}$ \\
\hline rata-rata & 3.25 & 3.42 & 3.58 & 3.50 & 3.75 & 3.75 & 3.67 & 3.42 & 3.92 & 3.50 \\
$\begin{array}{c}\text { Persentase } \\
\text { \%total }\end{array}$ & 81.25 & 85.42 & 89.58 & 87.50 & 93.75 & 93.75 & 91.67 & 85.42 & 97.92 & 87.50 \\
\hline
\end{tabular}

Tabel 7 menunjukkan hasil persentase total respon siswa 89,38 dengan kriteria positif.

Hasil Respon pada Uji Kelompok Besar

Adapun respon siswa pada uji kelompok besar dapat dilihat pada Tabel 8.

Tabel 8. Hasil Respon Siswa pada Uji Kelompok Besar

\begin{tabular}{ccccccccccc}
\hline \multirow{2}{*}{ Siswa } & \multicolumn{10}{c}{ Pernyataan } \\
\cline { 2 - 11 } & $\mathbf{1}$ & $\mathbf{2}$ & $\mathbf{3}$ & $\mathbf{4}$ & $\mathbf{5}$ & $\mathbf{6}$ & $\mathbf{7}$ & $\mathbf{8}$ & $\mathbf{9}$ & $\mathbf{1 0}$ \\
\hline rata-rata & 4.00 & 4.00 & 3.83 & 3.69 & 3.69 & 3.75 & 4.00 & 3.81 & 3.69 & 3.61 \\
$\begin{array}{c}\text { Persentase } \\
\text { \%total }\end{array}$ & 100.00 & 100.00 & 95.83 & 92.36 & 92.36 & 93.75 & 100.00 & 95.14 & 92.36 & 90.28 \\
\hline
\end{tabular}

Tabel 8 menunjukkan hasil persentase total respon siswa 89,38 dengan kriteria positif.

Adapun berbandingan hasil persentase angket respon siswa terhadap media pembelajaran berbasis android antara kelompok one to one, kelompok sedang dan kelompok besar dapat dilihat pada Gambar 1. 


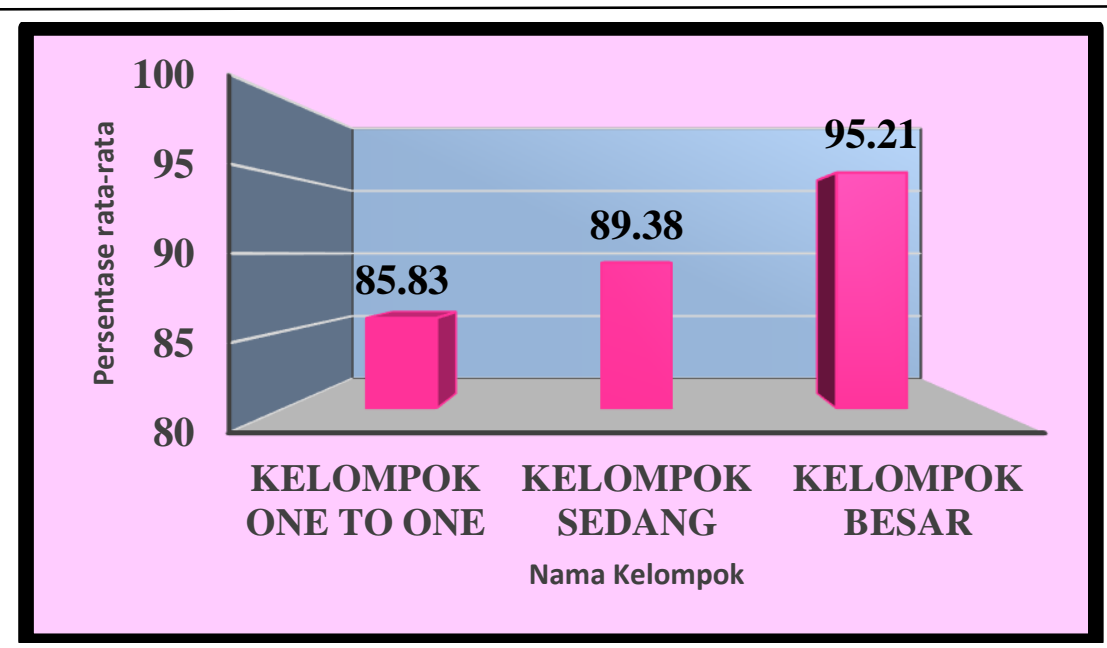

Gambar 1. Hasil Perbandingan Persentase Rata-Rata

Persentase dari uji one to one sebesar $85,83 \%$, uji kelompok sedang sebesar 89,38\%, dan uji kelompok besar sebesar 95,21\% dengan kategori positif. Hal ini menandakan bahwa media pembelajaran berbasis android ini dapat digunakan dalam pembelajaran fisika. Menggunakan media android dalam pembelajaran fisika dapat dijadikan alternatif dalam belajar fisika terutama bagi siswa. Dengan media android ini, siswa dapat belajar fisika baik di dalam maupun luar kelas. Selain kemampuan kognitif, penggunaan media android dalam belajar fisika juga mampu meningkatkan kemampuan lainnya seperti berpikir ilmiah dan tingkat tinggi (Dasilva, et al. (2019). Pengembangan media android dengan bentuk "othok-othok toy ship" mampu meningkatkan kompetensi siswa dalam merepresentasikan diagram dan argumentasi dalam pembelajaran fisika (Liliarti \& Kuswanto, 2018).

Media pembelajaran berbasis android ini adalah sebuah media pembelajaran yang dirancang dari microsoft powerpoint yang kemudian di-convert menjadi aplikasi dengan bantuan aplikasi Ispring Suite8 dan Website 2 APK Builder. Media ini dikembangkan untuk membantu guru dalam proses pembelajaran agar lebih menarik dan meningkatkan keaktifan siswa Penerapan dan pemanfaatan android telah banyak digunakan dan memberikan manfaat yang positif (Toifur \& Sulisworo, 2016). Media yang dimaksud dalam penelitian ini adalah media yang berbentuk aplikasi berbasis android yang telah diuji kevalidannya dan layak digunakan dalam pembelajaran fisika dan hasil uji coba terhadap siswa didapatkan hasil positif. Hal ini menunjukkan bahwa media pembelajaran berbasis android layak digunakan dalam pembelajaran fisika.

\section{SIMPULAN}

Tahapan yang dilakukan berkenaan dengan desain media pada materi gerak lurus beraturan dan gerak lurus berubah beraturan berbasis android siap dirancang dengan model ADDIE yang terdiri dari lima tahap yaitu analisis (analyze), desain (design), pengembangan (development), implementasi (implementation), dan evaluasi (evaluation). Pada tahap implementasi (implementation) meliputi uji coba penggunaan media pembelajaran berbasis android di SMA Negeri 3 Ngabang pada kelas IPA sebanyak 51 siswa. Pengembangan ini menghasilkan media pembelajaran berbasis android yang sudah diuji kevalidannya dan layak digunakan dalam pembelajaran fisika.

\section{REFERENSI}

Arikunto, S., and Safruddin, A. J. C. (2009). Evaluasi program pendidikan. Jakarta: Bumi Aksara. Asyhar, R. (2011). Kreatif mengembangkan media pembelajaran. Jakarta: Gaung Persada Press.

Astuti, I. A. D., Sumarni, R. A., \& Saraswati, D. L. (2017). Pengembangan media pembelajaran fisika mobile learning berbasis Android. Jurnal Penelitian \& Pengembangan Pendidikan Fisika, 3(1), 57-62. 
Dasilva, B.E., Ardiyati, T.K., Suparno, Sukardiyono, Eveline, E., Utami, T., \& Ferty Z.N. (2019). Development of android-based interactive physics mobile learning media (IPMLM) with scaffolding learning approach to improve hots of high school students. Journal for the Education of Gifted Young Scientists, 7(3), 659-681. DOI: http://dx.doi.org/10.17478/jegys.610377

Hermawan, H. D., \& Arifin, F. (2015, November). The development and analysis of quality of" Batik Detector" as a learning media for Indonesia Batik motifs Android based in Indonesian School of Singapore. In 2015 International Conference on Science and Technology (TICST) (pp. 281-287). IEEE.

Liliarti, N, and Kuswanto, H. (2018) Improving the competence of diagrammatic and argumentative representation in physics through android-based mobile learning application. International Journal of Instruction, 11(3), 106-122. https://doi.org/10.12973/iji.2018.1138a.

Muyaroah, S., \& Fajartia, M. (2017). Pengembangan Media Pembelajaran Berbasis Android dengan menggunakan Aplikasi Adobe Flash CS 6 pada Mata Pelajaran Biologi. Innovative Journal of Curriculum and Educational Technology, 6(2), 22-26.

Pribadi, B. A. (2016). Desain dan Pengembangan Program Pelatihan Berbasis Kompetensi Implementasi Model ADDIE. Kencana.

Riduwan. (2010). Skala pengukuran variabel-variabel penelitian. Bandung: Alfabeta.

Rusman. (2011). Pembelajaran berbasis teknologi informasi dan komunikasi, mengembangkan profesionalitas guru. Jakarta. Rajawali Pers

Sulisworo, D. \&Toifur, M. (2016) The role of mobile learning on the learning environment shifting at high school in Indonesia. int. J. Mobile Learning and Organisation, 10(3), 159-170.

Yektyastuti, R., \& Ikhsan, J. (2016). Pengembangan media pembelajaran berbasis android pada materi kelarutan untuk meningkatkan performa akademik siswa SMA. Jurnal Inovasi Pendidikan IPA, 2(1), 88-99. 